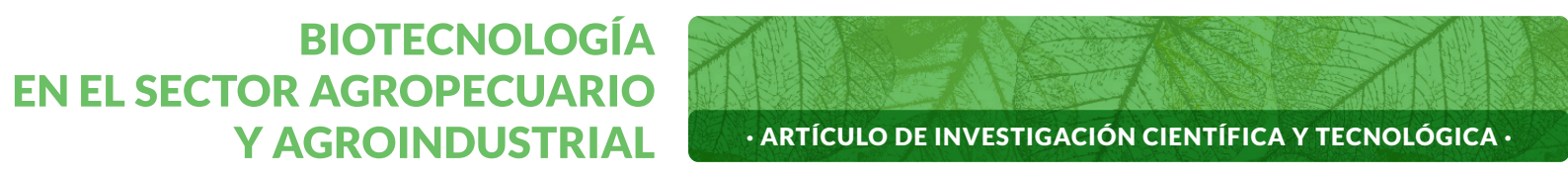

\title{
Evaluación de métodos para la inoculación y diagnóstico del virus del mosaico del pepino (CMV)*
}

\section{Evaluation of methods for inoculation and diagnosis of the cucumber mosaic virus (CMV)}

\section{Avaliação de métodos para inoculação e diagnóstico de vírus de mosaico do pepino (CMV)}

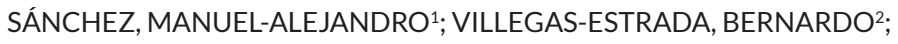

VALENCIA-JIMÉNEZ, ARNUBIO ${ }^{3}$

\section{Historial del Artículo}

Recibido para evaluación: 21 de Enero 2020.

Aprobado para publicación: 20 de Octubre 2020

* Proyecto de investigación de origen: "Efectos de la aplicación de secuencias de ARN de cadena doble (ARNcd) en el silenciamiento del virus del mosaico del pepino (CMV)". Financiación: Universidad de Caldas y Minciencias, códigos 0178917 y 1672118. Culminación: Agosto 6 de 2021.

1 Universidad del Caldas, Facultad de Ciencias Exactas y Naturales, Grupo de investigación Ciencias agronómicas y pecuarias (GICAP). Magíster en Ciencias Biológicas. Manizales, Colombia. https://orcid.org/0000-0002-2970-8825

2 Universidad de Caldas, Departamento de producción Agropecuaria, Grupo de Investigación InGene. Magíster en Fitopatología: Manizales, Colombia. https://orcid. org/0000-0003-4441-5278

3 Universidad de Caldas, Departamento de producción Agropecuaria, Grupo de Investigación InGene. Doctor en Ciencias Biológicas. Manizales, Colombia. https://orcid. org/0000-0003-3328-2932 


\section{RESUMEN}

El virus del mosaico del pepino (CMV) es un agente limitante en la producción y calidad de cultivos agrícolas cuya inoculación efectiva y diagnóstico confiable son esenciales para implementar estrategias de manejo adecuadas y oportunas. Se evaluaron dos protocolos para la inoculación del CMV en plantas indicadoras (Nicotiana benthamiana y N. tabacum cv. Xanthi) y diferentes métodos de detección de este virus. La infección de plantas con CMV se logró mediante transmisión mecánica e infiltración. La presencia del virus se confirmó mediante la expresión de síntomas, serología (ImmunoStrip $®), R T-P C R$ y por secuenciación. Los resultados confirmaron la efectividad del método de transmisión mecánica, en el cual, las plantas infectadas presentaron sintomatología asociada con el virus 15 días después de su inoculación. La prueba serológica permitió detectar la presencia del patógeno solo en las plantas de N. benthamiana, mientras que la prueba de $R T-P C R$ en todas las plantas evaluadas. Los resultados de secuenciación mostraron altos valores de identidad nucleotídica con las secuencias reportadas en el NCBI para este virus. La transmisión mecánica fue el método más efectivo para la inoculación del CMV y las técnicas de análisis molecular fueron más sensibles y confiables para su identificación, en comparación con la prueba serológica.

\section{ABSTRACT}

The cucumber mosaic virus (CMV) is a limiting agent in the production and quality of agricultural crops whose effective inoculation and reliable diagnosis are essential to implement suitable and timely management strategies. Two protocols for CMV inoculation (Nicotiana benthamiana and N. tabacum cv. Xanthi) as indicator plants and different virus detection methods were evaluated. Infection of plants with CMV was achieved by mechanical transmission and infiltration. The presence of the virus was confirmed by expression of symptoms, serology (ImmunoStrip $®), R T-P C R$ and by sequencing. The results confirmed the effectiveness of the mechanical transmission. The infected plants showed symptoms associated with the pathogen 15 days after inoculation. The serological test allowed detecting the presence of the pathogen only in N. benthamiana plants, while the RT-PCR test in all evaluated plants. The sequencing results showed high nucleotide identity values with the sequences reported in the NBCl for this virus. Mechanical transmission was the most effective method for CMV inoculation, and molecular analysis techniques were more sensitive and reliable for CMV identification, compared to serological test.

\section{RESUMO}

$O$ vírus do mosaico do pepino (CMV) é um agente limitante na produção e qualidade das culturas agrícolas cuja inoculação eficaz e diagnóstico confiável

Como citar este artículo: SÁNCHEZ, MANUEL-ALEJANDRO; VILLEGAS-ESTRADA, BERNARDO; VALENCIA-JIMÉNEZ, ARNUBIO. Evaluación de métodos para la inoculación y diagnóstico del virus del mosaico del pepino (CMV). Biotecnología en el sector agropecuario y agroindustrial, v. 19, n. 1, 2021, p. 92-104. Doi: https://doi. org/10.18684/BSAA(19)92-104

\section{PALABRAS CLAVE:} ImmunoStrip; Enfermedad; Serología.

\section{KEYWORDS:}

ImmunoStrip; Disease; Serology.

\section{PALAVRAS-CHAVE:}

ImmunoStrip; Doença; Serologia. 
são essenciais para implementar estratégias de manejo adequadas e oportunas. Foram avaliados dois protocolos de inoculação de CMV em plântulas indicadoras (Nicotiana benthamiana e N. tabacum cv. Xanthi) e diferentes métodos de deteç̧ão do vírus. A infecção com CMV foi obtida por transmissão mecânica e por infiltração. A presença do vírus foi confirmada pela expressão dos sintomas, serologia (ImmunoStrip $\left.{ }^{\circledR}\right)$, RT-PCR e sequenciamento. Os resultados confirmaram a eficácia da transmissão mecânica, no qual plântulas infectadas apresentaram sintomas associados ao vírus 15 dias após a inoculação. O teste serológico permitiu detectar a presença do patógeno apenas nas plantas de N. benthamiana, enquanto o teste RT-PCR em todas as plantulas avaliadas. Os resultados do sequenciamento mostraram altos valores de identidade de nucleotídeos com as sequências do vírus no NCBI. A transmissão mecânica foi o método mais eficaz para a inoculação do CMV e as técnicas de análise molecular foram mais sensíveis e confiáveis para identificação do CMV, em comparação com os testes serológicos.

\section{INTRODUCCIÓN}

Los virus, son los patógenos vegetales más importantes, después de los hongos [1]. Estos agentes biológicos provocan daños en muchos cultivos de interés agrícola [2], generando pérdidas económicas de miles de millones de dólares en todo el mundo [3]. Los cuatro virus vegetales más importantes desde el punto de vista científico y económico son: Tobacco mosaic virus (TMV), Tomato spotted wilt virus (TSWV), Tomato yellow leaf curl virus (TYLCV) y Cucumber mosaic virus (CMV) [4]. En Colombia se reportado la presencia del CMV en herbáceas (plátano, banano) [5], hortalizas (pepino, pimentón) [6], y frutales como lulo [7], entre otros.

EI CMV es probablemente uno de los patógenos vegetales más exitosos, ya que puede afectar a más de 1.200 especies de plantas [8]. Este virus es transmitido por los pulgones de manera no persistente [8], los cuales han sido utilizados como vectores para transmitir patógenos virales en condiciones ambientales controladas, sin embargo, su tasa de trasmisión es muy baja [9], lo que los hace poco prácticos a gran escala. Por su parte, la transmisión mecánica con savia infectiva, por medio de la inoculación, es la estrategia más utilizada en estudios de virus vegetales [10].

La transmisión mecánica efectiva ocurre si el virus puede replicarse en las células epidérmicas infectadas, y luego moverse a otros tejidos de la planta en donde pueda desarrollar centros infecciosos [11]. Se sabe que el CMV puede transmitirse mecánicamente e infectar plantas de manera eficiente, ya que su genoma codifica proteínas involucradas en el movimiento de célula a célula, así como también movimientos a través de los haces vasculares [12]. El genoma de este virus consta de tres segmentos de ARN monocatenarios de sentido positivo (ARN 1, ARN 2 y ARN 3). EI ARN 1 (3,4 kb) y el ARN 2 (2,2 kb) codifican para la expresión de las proteínas 1a y 2a respectivamente, las cuales están involucradas en la replicación y transcripción del virus. El ARN 2 igualmente codifica para la síntesis de la proteína $2 \mathrm{~b}$ la cual participa en la supresión del silenciamiento genético, y el ARN 3 $(3,0 \mathrm{~kb})$ codifica para proteínas de la cápside y del movimiento [13].

Debido a estas propiedades genómicas, el CMV causa un deterioro del estado normal de la planta, modificando o interrumpiendo funciones vitales (germinación transpiración, y fotosíntesis) [14]. Estas alteraciones del desarrollo en la planta a menudo conllevan a síntomas específicos como mosaicos, moteados, distorsión de la estructura de las hojas, y retraso en el crecimiento de las plantas afectadas [12]. Sin embargo, los síntomas pueden confundirse con aquellos causados por estrés biótico (infección por otros patógenos, daños por plagas) o por factores abióticos (condiciones climáticas desfavorables, desequilibrios nutricionales) [15]. Por lo tanto, un diagnóstico preciso y eficiente de este virus en etapas tempranas de la enfermedad representa una tarea importante y necesaria a la hora de implementar un manejo eficiente [16].

Actualmente, existen diferentes métodos orientados a la detección de virus, los cuales se basan en el empleo de microscopía electrónica, en técnicas serológicas y en enfoques moleculares. La microscopía electrónica es limitante debido a que solo determina la morfología de la partícula viral [17], las técnicas serológicas tienen una sensibilidad limitada, lo cual genera posibles inconvenientes a la hora de hacer la detección viral [18], y las técnicas moleculares, por su parte, permiten una detección más eficiente y sensible, superando las limitaciones de 
las técnicas tradicionales y serológicas [19]. Sin embargo, este último tipo de análisis depende, en gran medida, de la calidad del ARN extraído, lo cual puede eventualmente limitar su uso [20].

El objetivo principal de esta investigación fue evaluar, bajo condiciones controladas, la efectividad de dos métodos de inoculación del CMV en plantas indicadoras, y tres técnicas de diagnóstico.

\section{MÉTODO}

Los ensayos se llevaron a cabo en el Laboratorio de Biotecnología vegetal de la Universidad de Caldas, en la ciudad de Manizales-Caldas, ubicado a una altitud de $2.153 \mathrm{msnm}$ y cuyas condiciones ambientales promedio son temperatura de $19^{\circ} \mathrm{C}$ y humedad relativa de $80 \%$.

Las semillas de plantas indicadoras de Nicotiana benthamiana y N. tabacum L. cv Xanthi fueron proporcionadas por el Dr. Sadao Kobayashi del Centro de Investigación Tibaitatá (Agrosavia), y la cepa viral del CMV proporcionada por el Dr. Wilmer Cuellar, director de la Unidad de Virología del Centro Internacional de Agricultura Tropical-CIAT (Palmira-Valle del Cauca). Las plantas indicadoras crecieron en una cámara de ambiente semi-controlado cuyo rango de temperatura fue de 22 a $26^{\circ} \mathrm{C}$, humedad relativa de 60 a $80 \%$ y fotoperiodo de $16 / 8$ horas (luz/oscuridad). La siembra y establecimiento del material vegetal de ambas especies consistió en una etapa de pre-germinación de las semillas sumergidas en agua, en condiciones de luz constante durante tres días. Como sustrato se empleó una mezcla de arena y tierra estériles en proporción 1:2.

\section{Inoculación del CMV}

El inóculo del CMV fue preparado a partir de una muestra liofilizada de material vegetal infectado, del cual se tomó $0,1 \mathrm{~g}$ de tejido y se maceró con $1,5 \mathrm{~mL}$ de agua destilada estéril con la ayuda de un mortero mantenido a $4^{\circ} \mathrm{C}$.

Para los tratamientos se evaluaron 24 plantas indicadoras de ocho semanas de edad ( $12 \mathrm{de} \mathrm{N.} \mathrm{benthamiana} \mathrm{y} 12$ de N. tabacum) e igual número de plantas para el control. La inoculación del CMV se realizó sobre hojas con un diámetro comprendido entre 1,5 y $3,0 \mathrm{~cm}$, empleando dos procedimientos. El primero fue la transmisión mecánica frotando suavemente la savia con la ayuda del dedo índice sobre las hojas de las plantas indicadoras. El segundo fue mediante infiltración, realizando una punción en la vena principal de la hoja cerca de su ápice; luego, en el lugar de la punción se inyectaron 0,1 mL de la savia infectada con el virus usando una jeringa sin aguja de 1 $\mathrm{mL}$ de capacidad. Las plantas control se inocularon con agua destilada estéril siguiendo el mismo procedimiento. En todos los casos, se emplearon seis repeticiones biológicas (unidades experimentales) por cada método de inoculación y por cada especie, en un diseño completamente al azar. Para determinar el grado de saturación de las hojas inoculadas con el extracto se llevó a cabo una infiltración con una solución al 1\% de rojo congo o calcofluor, con volúmenes entre 0,1 y $0,5 \mathrm{~mL}$ (datos no mostrados).

\section{Detección del CMV en las plantas inoculadas}

La efectividad de las vías de inoculación del CMV se evaluó mediante observación de la sintomatología en las plantas, por pruebas serológicas (ImmunoStrip $囚$ ) y mediante el empleo de análisis molecular (RT-PCR y secuenciación). Los procedimientos se describen a continuación:

\section{Sintomatología}

Se evaluaron los síntomas en hojas y el desarrollo general de la planta. Los síntomas se registraron a los 3, 15 y 21 días después de la inoculación (ddi). En la figura 1 se observa la escala de síntomas propuesta para la evaluación del CMV. 
Figura 1. Escala de síntomas para la virosis del CMV en hojas de N. benthamiana.
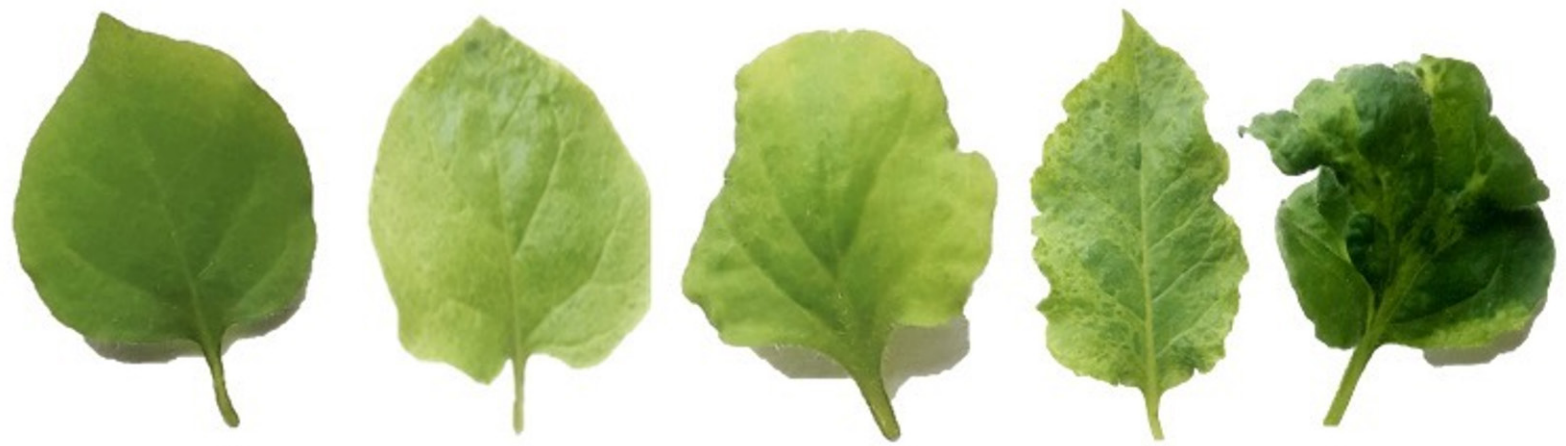

A. Grado 0= Hoja aparentemente sana. B. Grado 1= Hoja con mosaico leve, sin arrugamiento. C. Grado 2= Hoja con mosaico leve o deformación. D. Grado 3= Hoja con deformación y/o mosaicos moderados. E. Grado 4= Hoja con mosaico y/o deformación severa.

\section{Serología}

Esta prueba se realizó diez días después de la inoculación en cada una de las repeticiones biológicas. Para esto se utilizó el kit ImmunoStrip ${ }^{\circledR}$ para CMV (Agdia Inc., Elkhart, IN), colocando 0,1 g de la muestra vegetal en una bolsa con tampón de extracción, siguiendo las instrucciones dadas por el fabricante.

\section{Moleculares}

La detección molecular del virus se efectuó por RT-PCR y por secuenciamiento como prueba confirmatoria de los resultados de sintomatología y serología. De N. benthamiana, se tomó una y de N. tabacum dos plantas para los análisis moleculares a los 25 días después de realizada la inoculación; las cuales se codificaron así: P1 ( $N$. benthamiana), P2 y P3 (N. tabacum).

\section{RT-PCR}

Se extrajo ARN total, utilizando el kit PureLink ${ }^{\mathrm{TM}}$ RNA Mini Kit (Invitrogen, USA). De las muestras P1, P2 y P3 se maceraron $0,1 \mathrm{~g}$ de tejido foliar con sintomatología viral en $1 \mathrm{~mL}$ de buffer de lisis conteniendo $10 \mu \mathrm{L}$ de $\beta$-mercaptoetanol, siguiendo las instrucciones del fabricante. Al finalizar el procedimiento, el ARN total obtenido fue eluido con $30 \mu \mathrm{L}$ de agua estéril libre de ARNasas. El producto obtenido se visualizó en gel de agarosa al 1\% y se cuantificó con la ayuda de un nanodrop 2000 (Thermo Scientic, USA). La síntesis de ADNc se realizó empleando el kit Maxima H Minus First Strand cDNA (Thermo Scientific) siguiendo un método de dos etapas. En la primera etapa, se usó $1 \mu \mathrm{g}$ de ARN total de cada muestra, $1 \mu \mathrm{L}$ (dT) primer, $1 \mu \mathrm{L}$ de dNasa, $1 \mu \mathrm{L}$ de dNTPmix $(10 \mathrm{mM})$, y posteriormente el volumen se aforó a $10 \mu \mathrm{L}$ con agua libre de nucleasas, y el volumen final se dejó a temperatura de $65^{\circ} \mathrm{C}$ por 5 minutos en un termociclador C1000 Touch (Bio-Rad, Hercules, CA). En la segunda etapa se añadieron $4 \mu \mathrm{L}$ de buffer $(5 \mathrm{x})$ y $1 \mu \mathrm{L}$ de enzima máxima $\mathrm{H}$. Las muestras se sometieron finalmente a $50^{\circ} \mathrm{C}$ durante 30 min y después a $85^{\circ} \mathrm{C}$ por 5 min parar la reacción. El ADNc sintetizado se almacenó a $-20^{\circ} \mathrm{C}$.

La RT-PCR se realizó con $2 \mu \mathrm{L}$ de una dilución 1:50 de ADNc, en un volumen final de reacción de $10 \mu \mathrm{L}$, el cual incluyó $5 \mu \mathrm{L}$ de Master-mix (Catálogo No. AB-0575; Thermo Scientific) (solución tampón, MgCl2, dNTP y Taq polimerasa), 0,5 $\mu \mathrm{L}$ de cebadores $(10 \mu \mathrm{M})$ (sentido y antisentido), y $2,5 \mu \mathrm{L}$ de agua libre de nucleasas. Finalmente, esta mezcla se llevó a termociclador a $95^{\circ} \mathrm{C}$ durante $5 \mathrm{~min}$, seguidos $95^{\circ} \mathrm{C}$ por $30 \mathrm{seg}, 60^{\circ} \mathrm{C}$ por $30 \mathrm{seg}, 72^{\circ} \mathrm{C}$ durante 1 min con 36 ciclos, con una extensión final de $72^{\circ} \mathrm{C}$ durante $10 \mathrm{~min}$. Los cebadores empleados en la RT-PCR se diseñaron con la ayuda de la herramienta bioinformática Oligoperfect Primer designer (www.thermofisher.com/), cinco juegos de cebadores (Cuadro 1), uno por cada gen del CMV, fueron enviados a Invitrogen (www.thermofisher.com) para su síntesis. 
Cuadro 1. Cebadores para amplificación por RT-PCR de los genes del CMV..

\begin{tabular}{|c|c|c|c|}
\hline Nombre del cebador & Secuencia del oligonucleótido (5'-3') & $\begin{array}{l}\text { Tamaño del } \\
\text { amplicon (bp) }\end{array}$ & Gen objetivo \\
\hline M1 & $\begin{array}{l}\text { F: GCGTTATCCACGCTGGTATT } \\
\text { R: AAATCCGCACTGTTTTCCAC }\end{array}$ & 165 & Replicación (ORF1a/ARN1) \\
\hline M2 & $\begin{array}{l}\text { F: TGGATGTCAGCGAGAGTGTC } \\
\text { R: ATACGCATGGGTTTGACCAT }\end{array}$ & 172 & Transcripción (ORF2a/ARN2) \\
\hline M3 & $\begin{array}{l}\text { F: CAAAAGTCCCAGCGAGAGAG } \\
\text { R: GGCGAACCAATCTGTATCGT }\end{array}$ & 190 & $\begin{array}{l}\text { Supresión de silenciamiento (ORF2b/ } \\
\text { ARN2) }\end{array}$ \\
\hline M4 & $\begin{array}{l}\text { F: AATCGTAAGCGGTGTTTTGC } \\
\text { R: AGCTGACGGTTTTGTTTGCT }\end{array}$ & 192 & Proteína de movimiento (ORF3a/ARN3) \\
\hline M5 & $\begin{array}{l}\text { F: AACCAGTGCTGGTCGTAACC } \\
\text { R: GCGTTCACTCCCTACAAAGG }\end{array}$ & 172 & $\begin{array}{l}\text { Proteína de cápside } \\
\text { (ORF3b/ARN3) }\end{array}$ \\
\hline
\end{tabular}

Los fragmentos amplificados se llevaron a cámara de electroforesis (Horizon ${ }^{\circledR} 58$ ) en geles de agarosa al $1 \%$ en tampón TAE pH 8. La visualización de los productos se efectuó empleando GelRed ${ }^{\circledR}$ (Cat.No.41010. Biotium) en relación 1:1. Como marcador de peso molecular se utilizó el DNA Ladder-1kb (Promega) (Cat.No.M102R GenScript). La electroforesis se llevó a cabo a $120 \mathrm{~V}$ por $30 \mathrm{~min}$. Los fragmentos amplificados se visualizaron con la ayuda de un Transiluminador Molecular Imager ${ }^{\circledR}$ Gel Doc ${ }^{T M} X R$ (BIO-RAD).

Los amplicones del tamaño esperado se purificaron con el kit ExoSAP-IT ${ }^{\mathrm{TM}}$ (Cat.No.78200. Applied Biosciences), siguiendo las instrucciones del fabricante. Las muestras (P1, P2 y P3) para secuenciamiento se prepararon incluyendo el cebador M4 antisentido y se enviaron a Eurofins Scientific (Des Moines, IA, USA). Las secuencias obtenidas se verificaron y editaron manualmente utilizando el software Finch TV_1_4_0 construyéndose secuencias consenso y confirmando su identidad por comparación con los datos depositados en el GenBank del NCBI, mediante BLAST.

\section{RESULTADOS}

\section{Métodos de detección del CMV}

\section{Detección viral por sintomatología}

En plantas de N. benthamiana inoculadas mediante transmisión mecánica se observó corrugamiento leve, mientras que las plantas inoculadas por infiltración presentaban encogimiento de la hoja tratada a los tres ddi. Estas observaciones posiblemente se deban a un estrés ocasionado por las técnicas per se, lo cual no afectó el procedimiento de inoculación.

En la segunda evaluación (15 ddi), el 91,6\% de las plantas de N. benthamiana inoculadas mecánicamente mostraron síntomas de posible origen viral, mientras que, solo el $25 \%$ de las plantas de esta misma especie inoculadas por infiltración, mostraron igual sintomatología. En ambos casos, las plantas también mostraron síntomas en hojas nuevas como mosaicos cloróticos y encrespamiento, tal y como se observa en la figura $2 \mathrm{~A}$ con los diferentes grados severidad.

A los 21 ddi, las plantas inoculadas presentaron síntomas evidentes de infección viral, manteniéndose estable el número de plantas enfermas respecto a la segunda observación. Los datos obtenidos muestran que la inoculación mecánica fue más eficiente con un $90 \%$ de plantas enfermas en comparación con la metodología de infiltración (21\%) (figura 2B). 
Figura 2. Sintomatología del CMV en hojas de N. benthamiana evaluadas a dos tiempos después de inoculación.
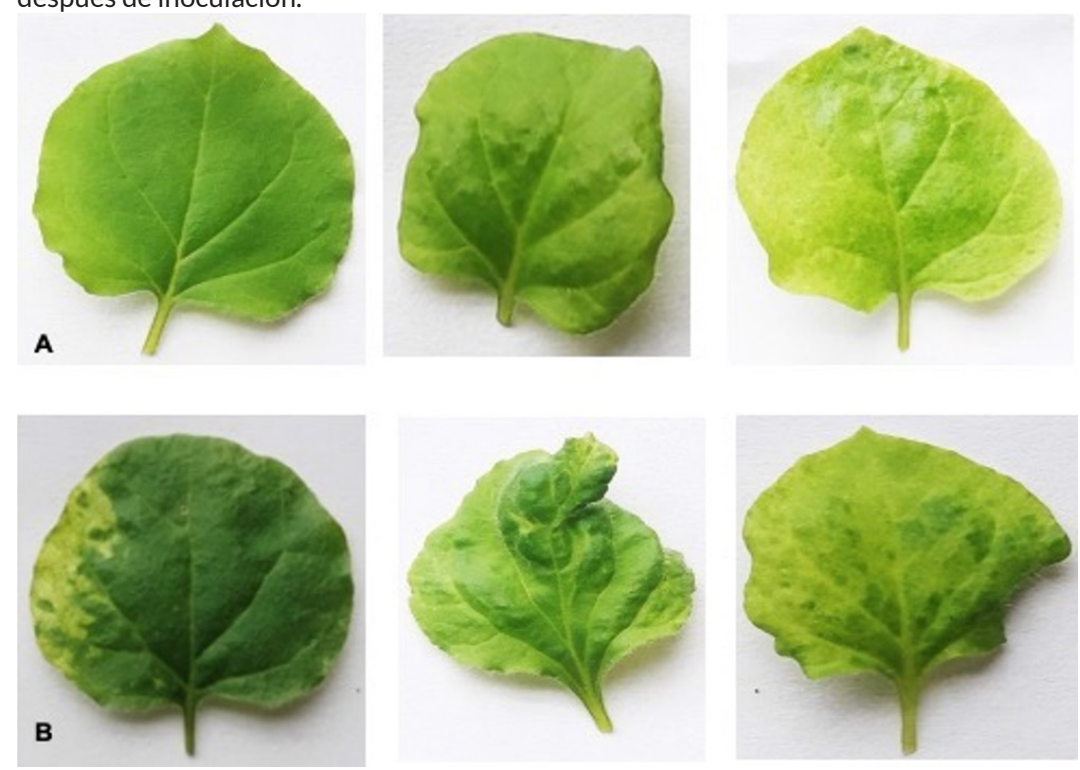

A. Hoja control inoculada con agua (Izquierda), hoja grado 2 con leve encrespamiento (centro) y hoja grado 3 con mosaico (derecha) a los 15 ddi. B. Hoja grado 3 con mancha clorótica (izquierda), hoja grado 5 con deformación (centro) y hoja grado 3 con deformación y mosaico fuerte (derecha) a los $21 \mathrm{ddi}$.

Respecto de las plantas de N. tabacum inoculadas con CMV mediante transmisión mecánica, solo el 33,3\% presentaron sintomatología a los $15 \mathrm{ddi}$, en forma de manchas cloróticas y mosaicos leves (datos no mostrados); mientras que las plantas inoculadas por infiltración ninguna presentó sintomatología viral.

En este estudio, se identificaron factores que influyen en la transmisión efectiva del CMV, incluida la edad de las plantas al momento de la inoculación y la temperatura del entorno. La trasmisión por inoculación mecánica favoreció la infectividad viral, lo cual se debe posiblemente a que la savia conserva una mayor concentración y estabilidad de las partículas virales [21].

El análisis visual realizado sobre las plantas inoculadas permitió la detección a los 15 ddi de síntomas característicos de infección por CMV (mosaico, enanismo encrespamiento y malformación de las hojas), lo que confirma inicialmente la presencia viral. Estos resultados concuerdan con los reportados por Troiano et al. [22], quienes observaron sintomatología viral 14 días después de la inoculación mecánica en plantas de Nicotiana spp. Del mismo modo, Jalender et al. [23] demostraron que al inocular mecánicamente plantas indicadoras con CMV, se obtienen síntomas evidentes a los 10-15 ddi, indicando que la concentración del virus aumenta a través del tiempo.

No obstante, Dheepa y Paranjothi [24] evaluando métodos de transmisión mecánica del CMV reportaron plantas de tabaco maduras que expresaban síntomas característicos de infección del virus, tres meses después de la inoculación. Estos resultados pueden atribuirse a variables ambientales, a condiciones de crecimiento, y a la edad de la planta al momento de la infección [25]. Este último factor juega un papel importante, ya que en plantas jóvenes el metabolismo es más activo, lo cual es aprovechado por los virus para su replicación y trascripción, lo que se traduce en una aparición más rápida de los síntomas [26].

Es importante destacar que en este estudio las plantas de N. benthamiana y N. tabacum presentaron síntomas típicos causados por el CMV cuando la temperatura osciló entre 24 y $26^{\circ} \mathrm{C}$ en etapa temprana después de la inoculación. Igual resultado obtuvieron Zhao et al. [27], quienes reportaron síntomas severos en N. tabacum en etapa 
temprana después de la inoculación del $\mathrm{CMV}$ a $28^{\circ} \mathrm{C}$, asociado a un mayor nivel de replicación viral, indicando que la temperatura es un factor ambiental importante que controla el crecimiento y la respuesta inmune de la planta.

\section{Detección viral mediante ImmunoStrip $®$}

La prueba serológica para CMV realizada mediante el empleo de las tirillas de ImmunoStrip ${ }^{\circledR}$, confirma la presencia del virus en las plantas de N. benthamiana, las cuales presentaron sintomatología, independiente del método de inoculación (figura 3A). Sin embargo, al evaluar las plantas de N. tabacum que presentaron sintomatología de posible presencia viral, el resultado de esta prueba fue no concluyente (figura 3B).

Figura 3. Test de ImmunoStrip ${ }^{\circledR}$ para la detección del CMV en plantas indicadoras. A. Test para CMV en N. benthamiana (P1). B. Test para CMV en N. tabacum (P2).
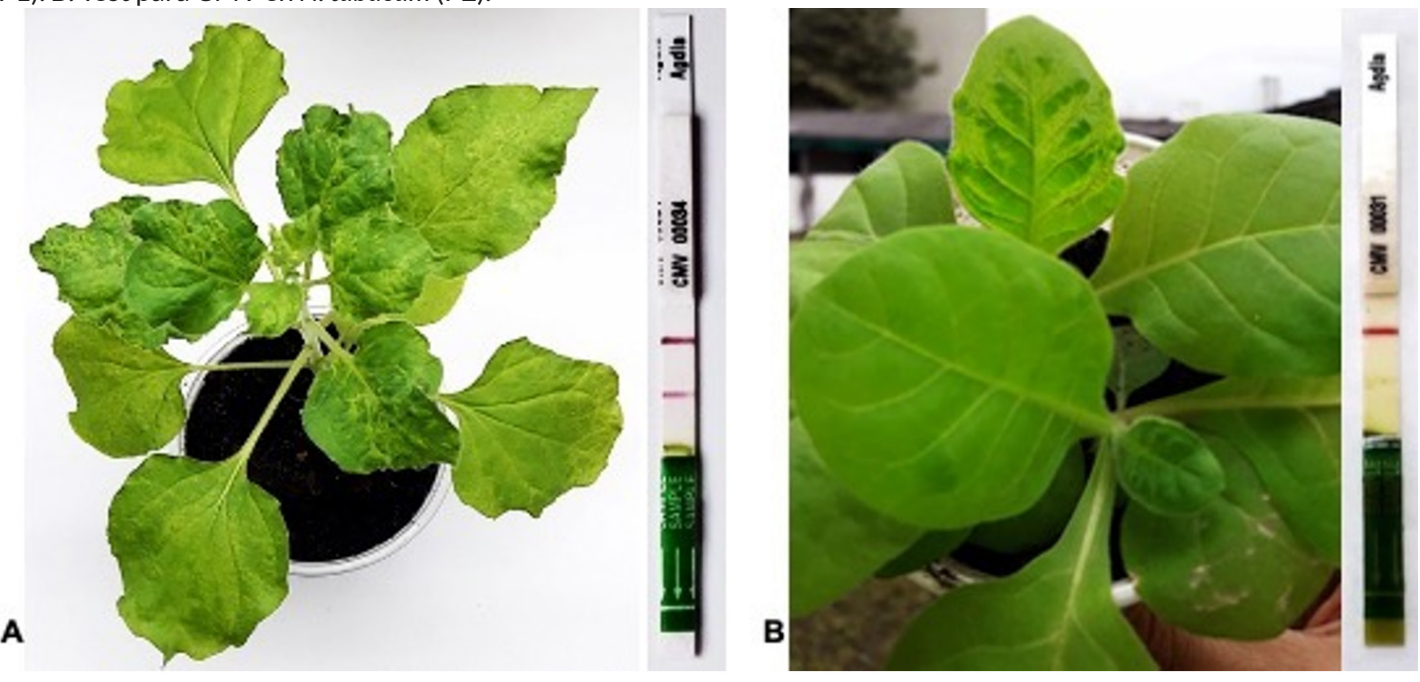

Un estudio realizado por Alhares y Al-Fadhel [28] en plantas indicadoras permitió identificar la presencia del CMV a través del empleo de ImmunoStrip ${ }^{\circledR}$. Kwon et al. [29] también usaron esta técnica para comprobar que el CMV era el agente causal de manchas cloróticas y de malformación en plantas indicadoras. Del mismo modo, Chikh-Ali et al. [30] confirmaron mediante inmuno-tiras, la presencia de PVY, en la que el extracto de hojas de papa maceradas reaccionó con los anticuerpos específicos para este virus, mientras que en otras investigaciones se ha obtenido buena sensibilidad con el uso de inmuno-tiras [31, 32, 33].

Aunque las publicaciones mencionadas anteriormente reportan una buena sensibilidad para detectar la prevalencia viral, en este estudio, las muestras P2 y P3 no presentaron evidencia de infección tras realizar ensayos con ImmunoStrip ${ }^{\circledR}$. Una posible explicación a este resultado (no concluyente), podría deberse a la baja concentración de partículas virales en las hojas analizadas [34], a una posible distribución desigual de las partículas del CMV en toda la planta, o a diversas tasas de translocación del virus en la planta [35].

Por lo anterior, los resultados obtenidos con las muestras P2 y P3 están acordes con los reportados por Liebenberg et al. [36], quienes evaluaron tirillas de ImmunoStrip ${ }^{\circledR}$ al compararlas con pruebas de DAS-ELISA y RT-PCR en 23 muestras de Vid para el Virus de la hoja en abanico de la vid (GFLV), encontrando que las tirillas no detectaron la presencia viral en el 17,4\% del material evaluado. De forma similar, Simmons et al. [37] realizaron una verificación experimental de la transmisión del Zucchini yellow mosaic virus (ZYMV) usando pruebas de RT-PCR e ImmunoStrip $®$, mostrando que la prueba serológica no logra la identificación efectiva del virus. 


\section{Detección por RT-PCR}

Se evaluó la eficiencia del protocolo de extracción de ARN teniendo en cuenta la calidad y la concentración final del ARN obtenido. La calidad, medida en función del radio $260 \mathrm{~nm} / 280 \mathrm{~nm}$ presentó valores entre 2,01 y 2,11, indicando una buena calidad del producto. En cuanto a la concentración se obtuvieron valores entre 328 y 734 ng. $\mu \mathrm{L}^{-1}$. Así mismo, la calidad y cantidad del ARN extraído se evaluó por separación electroforética en geles de agarosa, observando bandas bien definidas de ARN ribosomal (datos no mostrados).

La detección de la presencia del CMV por PCR se realizó en tejidos de hojas sintomáticas a los 25 después de efectuada la inoculación con el virus, utilizando para esto cebadores específicos (cuadro 1). La reacción de PCR con los ADNc de las muestras evaluadas permitió generar amplicones entre 165 y 190 pb, los cuales corresponden a los tamaños esperados (figura 4).

Los productos de PCR de las tres muestras enviadas a secuenciamiento confirmaron la presencia del CMV en las plantas inoculadas. Al comparar las secuencias consenso que codifican para la proteína de movimiento del CMV, con las publicadas en el banco de genes del NCBI, se observó $99 \%$ de identidad, resultado que confirma la presencia del CMV en las plantas de N. benthamiana y N. tabacum.

La técnica de RT-PCR permitió la identificación efectiva del CMV en el material analizado, incluidas aquellas muestras en las cuales no se logró la detección mediante la técnica de ImmunoStrip ${ }$. Resultados similares se reportan en los estudios de Stammler et al. [38], quienes emplearon técnicas moleculares para la detección de patógenos, como una metodología alternativa para la validación de resultados de diagnóstico basados en pruebas serológicas. Así mismo, lqbal et al. [39] demostraron la utilidad de los métodos moleculares para evaluar la incidencia del CMV en cultivos vegetales. Por su parte, Culal-Kilic et al. [40] reportan una mayor sensibilidad de la PCR en la detección de Tomato Spotted Wilt Virus (TSWV) con respecto a métodos serológicos.

Por otro lado, los altos niveles de identidad encontrados en este estudio por secuenciación (99\%), coinciden con los reportados por Riascos et al. [41] y Mejía et al. [42], quienes identificaron virus vegetales usando RT-PCR y secuenciación de fragmentos de PCR, mostrando alta sensibilidad de detección viral entre las metodologías moleculares evaluadas. A pesar que los resultados de RT-PCR confirmaron la presencia viral en este estudio,

Figura 4. Electroforesis en gel de agarosa de productos de PCR de una muestra positiva para CMV, MM: marcador de peso molecular, M1 al M5; cebadores.

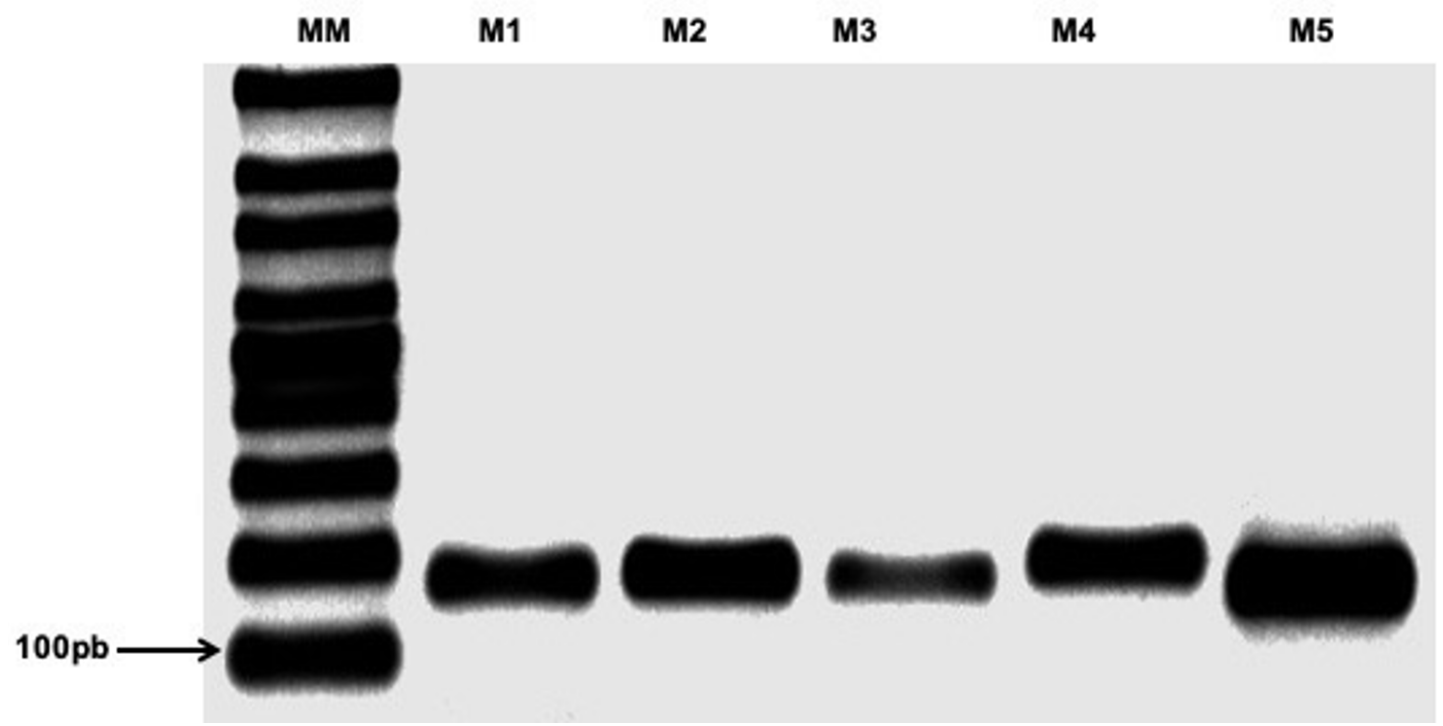


resulta importante incluir pruebas de detección que se apoyen en análisis de las secuencias de los productos de PCR generados, esto con el fin de evitar falsos positivos que podrían conducir a generar diagnósticos erróneos.

\section{CONCLUSIONES}

La transmisión mecánica del CMV fue más efectiva que la inoculación por infiltración, representando un método que facilita los estudios de diagnóstico y manejo de virus vegetales.

La RT-PCR fue más sensible y confiable que la prueba serológica (ImmunoStrip $®)$ para la detección del virus en estudio.

\section{AGRADECIMIENTOS}

Los autores expresan sus agradecimientos a Minciencias y la Universidad de Caldas, por la financiación de esta investigación en el marco del Proyecto "Efectos de la aplicación de secuencias de ARN de cadena doble (ARNcd) en el silenciamiento del virus del mosaico del pepino (CMV)" códigos 0178917 y 1672118.

\section{REFERENCIAS}

[1] ZHAO, LEI; FENG, CHAOHONG; WU, KUAN; CHEN, WENBAO; CHEN, YUJIA; HAO, XINGAN; WU, YUNFENGAdvances and prospects in biogenic substances against plant virus: A review. Pesticide biochemistry and physiology, v. 135, 2017, p. 15-26. https://doi.org/10.1016/j.pestbp.2016.07.003

[2] GAUR, RAJARSHI-KUMAR; KHURANA, PAUL; DOROKHOV, YURI (Eds.). Plant Viruses: Diversity, Interaction and Management. Boca Raton-FL (USA): CRC Press, 2018, 387 p.

[3] HAMMOND, ROSEMARIE. Economic significance of viroids in vegetable and field crops. En: Viroids and satellites. London (UK): Academic Press: 2017, p. 5-13. https://doi.org/10.1016/B978-0-12-801498-1.00001-2

[4] SCHOLTHOF, KAREN-BETH; ADKINS, SCOTT; CZOSNEK, HENRYK; PALUKAITIS, PETER; JACQUOT, AMMANUEL; HOHN, THOMAS; HOHN, BARBARA; SAUNDERS, KEITH; CANDRESSE, THIERRY; AHLQUIST, PAUL; HEMENWAY, CYNTHIA; FOSTER, GARY. Top 10 plant viruses in molecular plant pathology. Molecular Plant Pathology, v, 12, n. 9, 2011, p. 938-954. https://doi.org/10.1111/j.1364-3703.2011.00752.x

[5] VIVEROS-FOLLECO, YOHANA-MARITZA; GUZMÁN-PIEDRAHITA, ÓSCAR-ADRIÁN; VILLEGAS-ESTRADA, BERNARDO. Enfermedades en viveros comerciales de Musa AAB 'Dominico hartón' en el departamento de Caldas, Colombia. Boletín científico centro de museos museo de Historia Natural, v. 21, n. 2 , 2017, p, 61-80. http://dx.doi.org/10.17151/bccm.2017.21.2.5

[6] RODRÍGUEZ, MARLON H.; NIÑO, NANCY E.; CUTLER, JOSEPH; LANGER, JULIANE; CASIERRA-POSADA, FÁNOR; MIRANDA, DIEGO; BANDTE, MARTINA; BÜTTNER, CARMEN. Certificación de material vegetal sano en Colombia: un análisis crítico de oportunidades y retos para controlar enfermedades ocasionadas por virus. Revista Colombiana de Ciencias Hortícolas, v. 10, n. 1, 2016, p. 164-175. http://dx.doi.org/10.17584/rcch.2016v10i1.4921

[7] GALLO, YULIANA; TORO, LUISA-FERNANDA; JARAMILLO, HELENA; GUTIÉRREZ, PABLO-ANDRÉS. Identificación y caracterización molecular del genoma completo de tres virus en cultivos de lulo (Solanum quitoense) de Antioquia (Colombia). Revista Colombiana de Ciencias Hortícolas, v. 12, n. 2, 2018 p. 281-292. http://doi.org/10.17584/rcch.2018v12i2.7692 
[8] PALUKAITIS, PETER; GARCIA-ARENAL, FERNANDO. Cucumoviruses. Advances in Virus Research, v. 62, 2003, p. 241-323. https://doi.org/10.1016/s0065-3527(03)62005-1

[9] AEBIG, JOAN A.; KAMO, KATHRYN; HSU, HEI-TI. Biolistic inoculation of gladiolus with Cucumber Mosaic Cucumovirus. Journal of virological methods, v. 123, n. 1, 2005, p. 89-94. https://doi.org/10.1016/j.jviromet.2004.09.010

[10] RAJAMANICKAM, S.; KUMAR, RAJESH; KARTHIKEYAN, G. A potential tool for the detection of plant viruses through serological and molecular approaches. Journal of Pharmacognosy and Phytochemistry, $v$. 8, n. 3, 2019, p. 3046-3051.

[11] HONG, JIN-SUNG; JU, HO-JONG. The plant cellular systems for plant virus movement. The plant pathology journal, v. 33, n. 3, 2017, p. 213-228. https://doi.org/10.5423/PPJ.RW.09.2016.0198

[12] MOCHIZUKI, TOMOFUMO; OHKI, SATOSHI. Cucumber mosaic virus: viral genes as virulence determinants. Molecular plant pathology, v. 13, n. 3, 2012, p. 217-225. https://doi.org/10.1111/j.1364-3703.2011.00749.x

[13] NOURI, SHAHIDEH; ARÉVALO, RAFAEL; FALK, BRYCE; GROVES, RUSSELL. Genetic structure and molecular variability of Cucumber Mosaic Virus isolates in the United States. PLoS One, v. 9, n. 5, 2014, p. e96582. 10.1371/journal.pone.0096582

[14] QIU, Y.; WANG, C.; ZHU, S. A Review on the Pathogenicity of Cucumber Mosaic Virus. Agricultural Biotechnology, v. 7, n. 1, 2018, p. 87-91.

[15] GONZÁLEZ-GARZA, RAMIRO. Evolution of diagnostic technics for plant viruses. Revista Mexicana de Fitopatología, v. 35, n. 3, 2017, p. 591-610. https://doi.org/10.18781/R.MEX.FIT.1706-1

[16] VARMA, ANUPAM; SINGH, MANOJ-KUMAR. En: Applied Plant Virology: Advances, Detection, and Antiviral Strategies. Diagnosis of plant virus diseases. Cambridge (USA): Academic Press, 2020, p. 79-92. https://doi.org/10.1016/B978-0-12-818654-1.00006-2

[17] BALODI, REKHA; BISHT, SUNAINA; GHATAK, ABHIJEET. Plant disease diagnosis: Technological advancements and challenges. Indian Phytopathology, v. 70, n. 3, 2017, p. 275-281. 10.24838/ip.2017.v70.i3.72487

[18] KIRANKUMAR, K.C.; PRIYA, N.; JAYASUDHA, S.M.; BHAT, GOUREESH. En: Applied Plant Virology: Advances, Detection, and Antiviral Strategies. Advances in protein-based diagnostic tools of plant viruses. Cambridge (USA): Academic Press, 2020. p. 93-99. https://doi.org/10.1016/B978-0-12-818654-1.00007-4

[19] BUITRÓN-BUSTAMANTE, JOHANNA-LISETH; MORILLO-VELASTEGUI, EDUARDO. Estandarización de un método de detección molecular del Cucumber mosaic virus (CMV) en banano ecuatoriano. Ciencia y Tecnología Agropecuaria, v. 18, n. 1, 2017, p. 113-124. http://dx.doi.org/10.21930/rcta.vol18_num1_art:562

[20] HAJIA, MASOUD. Limitations of different PCR protocols used in diagnostic laboratories: a short review. Modern Medical Laboratory Journal, v. 1, n. 1, 2017, p. 1-6.

[21] YADAV, KAVITA; YADAV, PRABHAT. The effect of different mechanism of transmission on transavaibility of Tomato Mosaic Virus. Journal of Pharmacognosy and Phytochemistry, v. 6, n. 6 2017, p. 448-450.

[22] TROIANO, ELISA; BELLARDI, MARIA-GRAZIA; PARRELLA, GIUSEPPE. Syringa vulgaris is a new host for Cucumber Mosaic Virus. Phytopathologia Mediterranea, v. 58, n. 2, 2019, p. 385-389. 10.14601/Phytopathol

[23] PORIKA, JALENDER; BHARATHI, BHAT. Studies on Transmission of Cucumber Mosaic Virus (CMV) by Sap Inoculation in Tomato. International Journal of Pure \& Applied Bioscience, v. 5, n. 4, 2017, p. 1908-1912. http://dx.doi.org/10.18782/2320-7051.5764

[24] DHEEPA, R.; PARANJOTHI, S. Transmission of Cucumber Mosaic Virus (CMV) infecting banana by aphid and mechanical methods. Emirates Journal of Food and Agriculture, 2010, p. 117-129. https://doi.org/10.9755/ejfa.v22i2.4899

[25] PAUDEL, DINESH-BABU; SANFAÇON, HÉLÉNE. Exploring the diversity of mechanisms associated with plant tolerance to virus infection. Frontiers in plant science, v. 9, 2018, p. 1575.

https://doi.org/10.3389/fpls.2018.01575 
[26] LEVY, D.; LAPIDOT, M. Effect of plant age at inoculation on expression of genetic resistance to tomato yellow leaf curl virus. Archives of virology, v. 153, n. 1, 2008, p. 171-179. https://doi.org/10.1007/s00705-007-1086-y

[27] ZHAO, FEIFEI; LI, YANAN; CHEN, LIJUAN; ZHU, LISHA; REN, HAN; LIN, HONGHUI; XI, DEHUI.Temperature dependent defence of Nicotiana tabacum against Cucumber Mosaic Virus and recovery occurs with the formation of dark green islands. Journal of Plant Biology, v. 59, n. 3, 2016, p. 293-301. 10.1007/s12374-016-0035-2

[28] ALFADHL, FADHL. Detection of cucumber mosaic virus on pepper by indicator plant immune strip and RT-polymerase chain reaction. Kufa Journal for Agricultural Sciences, v. 9, n. 4, 2017, p. 73-91.

[29] KWON, SUN-JUNG; YOON, JU-YEON; CHOI, GUG-SEOUN; CHO, IN-SOOK. First Report of Cucumber Mosaic Virus in Atractylodes macrocephala in Korea. Plant Disease, v. 103, n. 2, 2019, p. 380-380. https://doi.org/10.1094/PDIS-07-18-1181-PDN

[30] CHIKH-ALI, MOHAMAD; RODRIGUEZ-RODRIGUEZ, MARÍANA; GREEN, KELSIE; KIM, DONG-JUN; CHUNG, SANG-MIN; KUHL, JOSEPH; KARASEV, ALEXANDER. Identification and molecular characterization of recombinant Potato virus Y (PVY) in potato from South Korea, PVYNTN strain. Plant disease, v. 103, n. 1, 2019, p. 137-142. https://doi.org/10.1094/PDIS-05-18-0715-RE

[31] GREEN, KELSIE; CHIKH-ALI, MOHAMAD; HAMASAKI, RANDALL; MELZER, MICHAEL; KARASEV, ALEXANDER. Potato virus Y (PVY) isolates from Physalis peruviana are unable to systemically infect potato or pepper and form a distinct new lineage within the PVYc strain group. Phytopathology, v. 107, n. 11, 2017, p. 1433-1439. https://doi.org/10.1094/PHYTO-04-17-0147-R

[32] ALFADHL, FADHI; ZAGIER, S.S.S. Identification of Cucumber Mosaic Virus (CMV) on eggplant by using some of indicator plants, Immunostrip assay and reverse transcriptase-polymerase chain reaction (RTPCR). Kufa Journal for Agricultural Science, v. 9, n. 4, 2017, p. 92-107.

[33] SIDOROVA, TATIANA; MIKHAILOV, ROMAN; PUSHIN, ALEXANDER; MIROSHNICHENKO; DOLGOV, SERGEY. Agrobacterium-mediated transformation of Russian commercial cv. 'Startovaya' (Prunus domestica L.) with virus-derived hairpin RNA construct confers durable resistance to PPV infection in mature plants. Frontiers in plant science, v. 10, n. 286, 2019, p. 286. https://doi.org/10.3389/fpls.2019.00286

[34] LIEBENBERG, ANNERIE; FREEBOROUGH, MICHAEL-JOHN; VISSER, CHRIS; BELLSTEDT, DIRK; BURGER, JOHAN. Genetic variability within the coat protein gene of Grapevine fanleaf virus isolates from South Africa and the evaluation of RT-PCR, DAS-ELISA and ImmunoStrips as virus diagnostic assays". Virus research, v. 142, n. 1-2, 2009, p. 28-35. https://doi.org/10.1016/j.virusres.2009.01.016

[35] DUPUIS, BRICE. The movement of Potato virus Y (PVY) in the vascular system of potato plants. European Journal of Plant Pathology, v. 147, n. 2, 2017, p. 365-373. 10.1007/s10658-016-1008-5

[36] LIEBENBERG, ANNERIE; FREEBOROUGH, MICHAEL-JOHN; VISSER, CHRIS; BELLSTEDT, DIRK; BURGER, JOHAN. Genetic variability within the coat protein gene of Grapevine fanleaf virus isolates from South Africa and the evaluation of RT-PCR, DAS-ELISA and ImmunoStrips as virus diagnostic assays. Virus research, v. 142, n. 1-2, 2009, p. 28-35. https://doi.org/10.1016/j.virusres.2009.01.016

[37] SIMMONS, H.E.; HOLMES, E.C.; GILDOW, F.E.; BOTHE-GORALCZYK; STEPHENSON, A.G. Experimental verification of seed transmission of Zucchini yellow mosaic virus. Plant Disease, v. 95, n. 6, 2011, p. 751754. https://doi.org/10.1094/PDIS-11-10-0843

[38] STAMMLER, JOHANNA; OBERNEDER, ANITA; KELLERMANN, ADOLF; HADERSDORFEER, JOHANNES. Detecting potato viruses using direct reverse transcription quantitative PCR (DiRT-qPCR) without RNA purification: an alternative to DAS-ELISA. European Journal of Plant Pathology, v. 152, n. 1, 2018, p. 237-248.

https://doi.org/10.1007/s10658-018-1468-x 
[39] IQBAL, SHOMAILA; SHAH, HUSSAIN; ASHFAQ, MUHAMMAD; KHAN-KASSI, AJMAL. Standardization of PCR protocol to check diversity among Pakistani isolates of cucumber mosaic Cucumovirus (CMV) infecting chilli pepper. Journal of Entomology and Zoology Studies, v. 5, n. 3, 2017, p. 729-735.

[40] CULAL-KILIC, HANDAN; YARDIMCI, NEJLA; BAL-ALÍ; GUNES-ALÍ, DENIZ-FATMA. Sensitive detection of tomato spotted wilt virus from pepper plants by DAS-ELISA, RT-PCR and IC-RT-PCR. Romanian Biotechnological Letters, v. 22. n. 5, 2017, p. 12934-12939.

[41] RIASCOS-CHICA, MELISSA; GUTIÉRREZ-SÁNCHEZ, PABLO ANDRÉS; MARIN-MONTOYA, MAURICIO-ALEJANDRO. Identificación molecular de Potyvirus infectando cultivos de papa en el oriente de Antioquia (Colombia). Acta Biológica Colombiana, v. 23. n. 1, 2018, p. 39-50. http://dx.doi.org/10.15446/abc.v23n1.65683

[42] SIERRA-MEJÍA, ANDREA; GALLO-GARCÍA, YULIANA; ESTRADA-ARTEAGA, MEIKE; GUTIÉRREZ, PABLO-ANDRÉS; MARÍN-MONTOYA, MAURICIO. Detección molecular de seis virus de ARN en brotes de tubérculos de papa criolla (Solanum phureja) en Antioquia Colombia. Bioagro, v. 32, n. 1, 2020, p. 3-14. 